\title{
Mushrooms: A Potential Natural Source of Anti-Inflammatory Compounds for Medical Applications
}

\author{
Elsayed A. Elsayed, ${ }^{1,2}$ Hesham El Enshasy, ${ }^{3,4}$ Mohammad A. M. Wadaan, ${ }^{1}$ and Ramlan Aziz ${ }^{3}$ \\ ${ }^{1}$ Bioproducts Research Chair, Zoology Department, Faculty of Science, King Saud University, Riyadh 11451, Saudi Arabia \\ ${ }^{2}$ Natural and Microbial Products Department, National Research Centre, Dokki, Cairo 12311, Egypt \\ ${ }^{3}$ Institute of Bioproduct Development (IBD), Universiti Teknologi Malaysia (UTM), 81130 Skudai, Malaysia \\ ${ }^{4}$ City of Scientific Research and Technology Application, New Burg Al Arab, Alexandria 21934, Egypt
}

Correspondence should be addressed to Elsayed A. Elsayed; eaelsayed@ksu.edu.sa

Received 24 May 2014; Accepted 13 August 2014; Published 23 November 2014

Academic Editor: Julio Galvez

Copyright ( 2014 Elsayed A. Elsayed et al. This is an open access article distributed under the Creative Commons Attribution License, which permits unrestricted use, distribution, and reproduction in any medium, provided the original work is properly cited.

\begin{abstract}
For centuries, macrofungi have been used as food and medicine in different parts of the world. This is mainly attributed to their nutritional value as a potential source of carbohydrates, proteins, amino acids, and minerals. In addition, they also include many bioactive metabolites which make mushrooms and truffles common components in folk medicine, especially in Africa, the Middle East, China, and Japan. The reported medicinal effects of mushrooms include anti-inflammatory effects, with anti-inflammatory compounds of mushrooms comprising a highly diversified group in terms of their chemical structure. They include polysaccharides, terpenoids, phenolic compounds, and many other low molecular weight molecules. The aims of this review are to report the different types of bioactive metabolites and their relevant producers, as well as the different mechanisms of action of mushroom compounds as potent anti-inflammatory agents.
\end{abstract}

\section{Introduction}

In the human body, inflammation is considered to be part of the complex biological response to remove injury or harmful stimuli such as pathogens, damaged cells, or irritation. This response leads to many physical symptoms such as fever, pain, and swelling, as a result of many associated changes such as vasodilation, increased vascular permeability, and plasma extravasation. Nowadays, the nonsteroidal anti-inflammatory drugs (NSAIDs) are usually the most commonly administrated drug to reduce inflammation in the body. Many studies, however, have shown that the long-term administration of NSAIDs has the potential for significant side effects on the gastrointestinal tract (GIT). These include numerous harmful effects such as mucosal lesions, bleeding, peptic ulcers, and intestinal perforation $[1,2]$. Other studies, meanwhile, have suggested that the side effects of NSAIDs are not limited only to GIT but extend to other serious complications such as acute renal failure, nephrotic syndrome, hypertension, and cardiovascular toxicity [3-5]. Recently, therefore, much effort has been devoted towards the discovery of alternative anti-inflammatory compounds of plant origin as potential natural and safe medicines without the harmful side effects of NSAIDs [6-11]. While a variety of plants have traditionally been used in human medicine, mushrooms also have a long history as important components of folk medicine and have been widely used in the form of aqueous extracts in many African, Middle Eastern, European, Asian, and native Australian cultures for the treatment of different diseases as well as a preventive medicine [12-16].

Mushrooms are a very large and diversified group of macrofungi belonging to Basidiomycetes and Ascomycetes; with a cell cycle including the formation of sexual spores. The fungal spores for these two groups are located in a special structure called the basidium (for Basidiomycetes) or the ascus (for Ascomycetes), and such mushrooms can grow either above the earth (epigeous macrofungi), giving mainly umbrella like structures which include basidiospores, or at depths of $10-20 \mathrm{~cm}$ below the soil surface (hypogeous macrofungi or truffles). The latter of these belong mainly to 
Ascomycetes and usually grow in a symbiotic relationship with a host plant as ectomycorrhizal mushrooms (EMM).

Both types of mushrooms have considerable nutritional value, since they are rich sources of carbohydrates, proteins, free amino acids, and vitamins, as well as different essential minerals and trace elements $[17,18]$. They are also rich in many bioactive metabolites of high medicinal value such as lectins, polysaccharides, phenolics and polyphenolics, terpenoids, ergosterols, and volatile organic compounds [19-21]. Mushroom extracts have therefore been used medicinally in immunomodulator [22-25], antitumor/anticancer [26-30], antibacterial and antiviral [31-33], antioxidant [34-37], and antihypoglycaemic [38-40] applications and as active medicines in the prevention of cardiovascular diseases through their action as antiatherosclerotic agents [41]. In addition, many compounds of highly diversified chemical structures with anti-inflammatory activities have been isolated and purified from different types of mushrooms. It has been reported, for example, that water, methanolic, ethanolic, and ethyl acetate extracts of different epigeous and hypogeous mushrooms showed significant decreases in the activities of inflammatory mediators such as nitric oxide (NO), cytokines, and prostaglandins, thus inhibiting some macrophage functions and reducing cell inflammations.

\section{Inflammation and Cell Molecular Signaling}

Inflammation is a complex set of interactions among soluble factors and cells that can arise in any tissue in response to trauma, infections, or postischaemic, toxic, or autoimmune injury [42]. In normal cases, the body's response to inflammation is self-limiting through the downregulation of proinflammatory protein expression, the increased expression of anti-inflammatory proteins, and a reversal in the vascular changes that facilitated the initial immune cell recruitment process [43]. The processes leading to inflammation are usually linked to the activities of the cells involved in the restoration of tissue structure and function. When cells are exposed to immune stimulants, the proinflammatory cells, such as macrophages, monocytes, or other host cells, start to produce many molecular mediators which initiate the inflammation process. Of the various inflammatory biomarkers that are produced, the most well-known are interleukins (IL-1 $\beta$ ), IL-6; IL-8; tumour necrosis factor (TNF- $\alpha$ ); nuclear factor- $\kappa \mathrm{B}$ (NF$\kappa \mathrm{B})$, intercellular adhesion molecule-1 (ICAM-1), inducible type cyclooxygenase- (COX-) 2, prostaglandin E2 (PGE2); 5lipooxygenase (5-LOX); and inducible nitric oxide synthase (iNOS), which leads to the production of reactive nitrogen species such as nitric oxide (NO). Overproduction of these inflammatory mediators leads to different kinds of cell damage. In addition, prolonged inflammation causes many inflammatory diseases such as juvenile idiopathic arthritis (JIA), inflammatory bowel disease (IBD), multiple sclerosis, rheumatoid arthritis, gastritis, bronchitis, and atherosclerosis [44]. A strong link has also been established between long-term inflammation and the development of cancers [45]. In some types of cancer, inflammation occurs before malignant changes in the cells. In other types, oncogenic change induces an inflammatory microenvironment that promotes tumour development [46]. As a result, increased attention is now being focused on efforts to discover bioactive compounds which have the ability to suppress the production of inflammatory mediators. In this context, mushroom metabolites have been employed as potent, natural, and safe anti-inflammatory compounds based on their ability to reduce the production of inflammatory mediators through downregulation of the gene expression of different types of these inflammatory mediators.

\section{Anti-Inflammatory Compounds of Mushrooms and Modes of Action}

Mushrooms are widely used for their high nutritional value as a functional food. Additionally, they have been highly appreciated for their medicinal and therapeutic applications $[47,48]$. Edible mushrooms produce a vast diversity of bioactive compounds such as polysaccharides, proteoglucans, terpenoids, phenolic compounds, steroids, and lectins. These compounds have a wide range of therapeutic effects and can act as immune-modulatory, anticarcinogenic, antiviral, antioxidant, and anti-inflammatory agents $[16,20]$. The concentration and efficacy of the bioactive compounds are varied and depend on the type of mushroom, substrate applied, cultivation and fruiting conditions, stage of development, age of the fresh mushroom, storage conditions, and processing and cooking procedures [41]. Many of the bioactive compounds found in mushrooms exhibit significant antiinflammatory properties. Table 1 lists most of the well-known mushroom species reported in the literature as possessing anti-inflammatory activities, along with their bioactive compounds and the solvent applied for extraction.

3.1. Polysaccharides. Polysaccharides represent the major class of bioactive compounds found in mushrooms, and have been reported in most of the edible types. Bernardshaw et al. [49] investigated the effect of an aqueous polysaccharide extract of Agaricus blazei Murill on the stimulation of proinflammatory cytokine production in human monocytes and human vein endothelial cells in vitro. They reported that $A$. blazei extract is rich in $\beta(1,3)-, \beta(1,4)$-, and $\beta(1,6)$-D-glucans (Figure 1) and induces the release of proinflammatory cytokines (IL-1 $\beta$, IL-6, IL-8) and $\alpha$ TNF. Another research has also reported that $A$. blazei extract enhances local and systemic inflammation, upregulates proinflammatory molecules, and enhances leukocyte homing to atherosclerosis sites without affecting the lipoprotein profile [50].

Contrary to these results, reports have recently appeared indicating that polysaccharides from $A$. blazei exert antiinflammatory activities. Song et al. [51] investigated the antiinflammatory and antiallergic effects of the chloroformsoluble extract of $A$. blazei in mouse bone-marrow-derived mast cells (BMMCs). They found that the extract inhibited the production of IL-6 in phorbol myristate acetate (PMA) plus calcium ionophore A23187-stimulated BMMCs and downregulated the phosphorylation of the serine/threonine kinase AKT. Furthermore, the extract inhibited the degranulation of $\beta$-hexosaminidase, as well as the production of prostaglandin $\mathrm{D}(2)$ and leukotriene $\mathrm{C}(4)$. They concluded 
TABLE 1: Anti-inflammatory compounds of mushrooms.

\begin{tabular}{|c|c|c|c|c|}
\hline Mushroom species & $\begin{array}{l}\text { Biomaterial } \\
\text { source }\end{array}$ & $\begin{array}{c}\text { Extracting } \\
\text { solvent }\end{array}$ & Bioactive compound & References \\
\hline Agaricus blazei & WM & 1 & Polysaccharides & [51] \\
\hline \multirow[t]{2}{*}{ A. bisporus } & WM & 3 & $\begin{array}{l}\text { Pyrogallol, hydroxybenzoic acid derivatives, } \\
\text { flavonoids. }\end{array}$ & [91] \\
\hline & FB & 4 & Polysaccharide (fucogalactan) & {$[65]$} \\
\hline A. subrufescens & WM & 2 & Polysaccharide (proteoglucan) & {$[55]$} \\
\hline Agrocybe aegerita & FB & 3 & Fatty acids & {$[88]$} \\
\hline A. cylindracea & $\mathrm{FB}$ & 2 & Agrocybin & {$[98]$} \\
\hline Albatrellus caeruleoporus & $\mathrm{FB}$ & 3 & Phenolic compound (Grifolinones A, B) & {$[93,94]$} \\
\hline Amanita muscaria & FB & $2,3,4$ & Crude extract & [99] \\
\hline Boletus edulis & WM & 3 & polysaccharides, & {$[91]$} \\
\hline Cantharellus cibarius & WM & 3 & Pyrogallol, flavonoids, polysaccharides & {$[91]$} \\
\hline C. tubaeformis & WM & 2 & Polysaccharides & {$[74]$} \\
\hline Cordyceps militaris & $\mathrm{SC} / \mathrm{FB}$ & 4 & Crude extract & {$[100]$} \\
\hline C. pruinosa & $\mathrm{FB}$ & 3 & Crude extract & {$[101]$} \\
\hline Caripia montagnei & FB & 3 & Polysaccharides (Glucans) & {$[63]$} \\
\hline Cyathus africanus & SC & 5 & Diterpenoid & {$[76]$} \\
\hline C. hookeri & SC & 5 & Diterpenoid & {$[77]$} \\
\hline Daldinia childiae & $\mathrm{FB}$ & N.M. & Benzophenones (daldinals A-C) & {$[92]$} \\
\hline Elaphomyces granulatus & $\mathrm{FB}$ & 4 & Syringaldehyde, syringic acid & {$[19,96]$} \\
\hline Flammulina velutipes & WM & 4 & Polysaccharides & {$[72]$} \\
\hline Fomitopsis pinicola & SC & 4 & Polysaccharides & {$[102]$} \\
\hline \multirow{2}{*}{ Grifola frondosa } & SC & 5,6 & Agaricoglycerides & {$[97]$} \\
\hline & SC & 3,5 & $\begin{array}{l}\text { Ergosterol } \\
\text { (1-oleoyl-2-linoleoyl-3-palmitoylglycerol) }\end{array}$ & {$[103]$} \\
\hline \multirow{2}{*}{ Ganoderma lucidum } & $\mathrm{FB}$ & 4 & Triterpene & {$[78]$} \\
\hline & $\mathrm{FB}$ & 4 & Lucidenic acid, ganoderic acid & {$[81]$} \\
\hline \multirow[t]{2}{*}{ Geastrum saccatum } & $\mathrm{FB}$ & 4 & Polysaccharides ( $\beta$-glucans) & {$[104]$} \\
\hline & FB & $2,4,5$ & Crude extract & {$[82]$} \\
\hline \multirow[t]{3}{*}{ Inonotus obliquus } & $\mathrm{FB}$ & 8,5 & $\begin{array}{l}\text { Ergosterols, lanosterol, inotodiol, trametenolic } \\
\text { acid }\end{array}$ & {$[84]$} \\
\hline & FB & 3 & Crude extract & {$[83]$} \\
\hline & $\mathrm{FB}$ & 4 & Crude extract & {$[105]$} \\
\hline Lactarius deliciosus & WM & 3 & Pyrogallol, flavonoids & {$[91]$} \\
\hline L. rufus & FB & 2,4 & Polysaccharides: $(1 \rightarrow 3),(1 \rightarrow 6)$ - $\beta$-D-glucans & {$[64]$} \\
\hline Lentinus edodes & FB & 2 & $\begin{array}{l}\text { Heterogalactan (fucomannogalactan) with main } \\
\text { chain of }(1 \rightarrow 6) \text {-linked } \alpha \text {-D-glactopyranosyl unit }\end{array}$ & {$[66]$} \\
\hline L. polychrous & SC & 4 & Crude extract & {$[67]$} \\
\hline Lyophyllum decastes & $\mathrm{FB}$ & 3 & Polysaccharides: (1-3) and (1-6) $\beta$-D-glucans & {$[106]$} \\
\hline \multirow{2}{*}{ Phellinus linteus } & $\mathrm{FB}$ & 9 & Polysaccharides (proteoglycan) & {$[69]$} \\
\hline & $\mathrm{FB}$ & $4,7,9$ & Crude extract & {$[107]$} \\
\hline Pholiota nameko & WM & $4,6,10$ & Polysaccharides & {$[71]$} \\
\hline \multirow{2}{*}{ Pleurotus pulmonarius } & $\mathrm{FB}$ & N.M. & Polysaccharides $(1 \rightarrow 3),(1 \rightarrow 6)$-linked $\beta$-glucan & {$[60]$} \\
\hline & FB & 2,4 & Polysaccharides (Glucan) & {$[57]$} \\
\hline Poria cocos & SC & 4 & Polysaccharides & {$[108]$} \\
\hline Termitomyces albuminosus & $\mathrm{SC} / \mathrm{FB}$ & 4 & Crude polysaccharide extract & {$[68]$} \\
\hline
\end{tabular}

WM, whole mushroom; SC, submerged culture; FB, fruiting bodies.

Solvent: N.M., not mentioned; 1, chloroform; 2, water; 3, methanol; 4, ethanol; 5, ethyl acetate; 6, acetone; 7, n-hexane; 8, petroleum ether; 9 , n-butanol; 10, acetyl ether. 


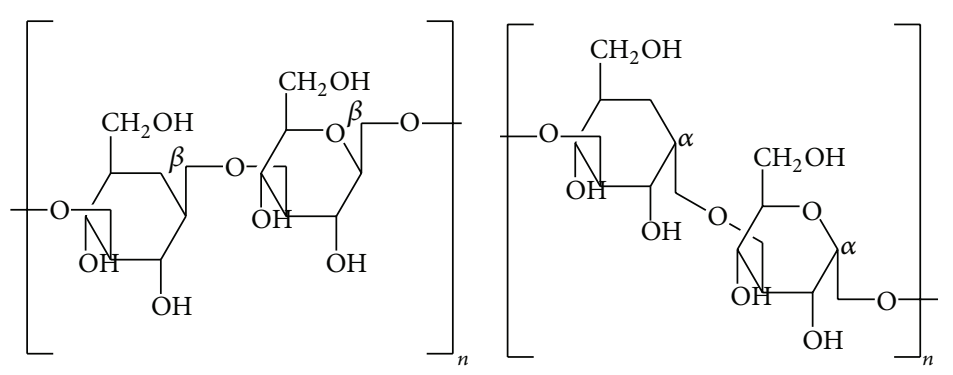

(a)

(b)

Figure 1: Molecular structure of $\beta$-(1 $\rightarrow 3)$-D-glucans (a) and $\alpha$-(1 $\rightarrow 3)$-D-glucans (b).

that their A. blazei extract has anti-inflammatory and antiallergic activities, which are regulated by affecting IL-6, prostaglandin $\mathrm{D}(2)$, leukotriene $\mathrm{C}(4)$, and the phosphorylation of the serine/threonine kinase AKT.

In 2009, Johnson et al. [52] reported a phase I clinical trial in which 15 healthy individuals were given a daily oral dose of $60 \mathrm{~mL}$ of aqueous extract of AndoSan (a mushroom extract mixture containing $82 \%$ A. blazei mycelium, 15\% Hericium erinaceum, and 3\% Grifola frondosa) for 12 days. Their results showed a significant in vivo reduction in the levels of IL$1 \beta$, TNF- $\alpha$, IL-6, IL-2, and IL-7 proinflammatory cytokines and unaltered levels of the remaining 12 cytokines. They concluded that the applied extract has an anti-inflammatory effect [52]. In 2011, they conducted another clinical pilot study in order to prove these results. They treated 21 hospitalized patients with inflammatory bowel diseases, ulcerative colitis, and Crohn's disease with the same AndoSan treatment dose (60 mL/d for 12 days). They noticed a significant decrease in plasma levels of the proinflammatory cytokines as well as a decrease in calprotectin, an inflammatory marker, in the faeces of ulcerative colitis patients [53].

Ellertsen and Hetland [54] attributed the apparently contradictory findings reported above to the fact that the effect of A. blazei extract differs according to the molecular size of active compound and the type of study performed (i.e., in vitro or in vivo). They found that in vitro cell culture studies showed increased proinflammatory cytokines, while in vivo human studies showed an anti-inflammatory response. They suggested that cells in vitro are affected by all substances present in the extract, including high molecular weight $\beta$ glucans. On the other hand, in human in vivo studies, it is mainly the smaller substances which are absorbed into the digestive tract to become active in blood. Additionally, they found that the regulatory genes of the leukocytes affected by the A. blazei extract differ in their expression in vitro and in vivo. Genes regulating proinflammatory cytokines were strongly induced in vitro, probably by the high molecular weight $\beta$-glucans, whereas, in vivo, genes controlling antiinflammatory reactions were upregulated, due to low molecular weight glucans. This hypothesis was supported by the mixed composition of the AndoSan extract, which contained both high and low molecular weight polysaccharides.

Other studies have reported that the protein-bound polysaccharides in the aqueous extract of $A$. subrufescens enhance defence mechanisms against invasive organisms and bacterial infection and reduce the plaque formation of viruses in cell cultures $[49,55,56]$.

Additionally, glucans $((1 \rightarrow 3)$ - $\beta$-D-glucopyranosyl) from Pleurotus pulmonarius have been reported to exhibit antiinflammatory properties [57-59]. These studies demonstrated that the fruiting body, or mycelial extract, of the edible mushroom markedly attenuated or suppressed symptoms associated with dextran sulphate sodium-induced acute colitis in mice. They also reported that, in an in vitro study, these glucans inhibited TNF- $\alpha$-dependent activation of NF- $\kappa \mathrm{B}$ in human intestinal cells [57]. Furthermore, $\beta$-glucans from $P$. pulmonarius exhibited an anti-inflammatory response in a model of acute colitis in rats, and when those from $P$. ostreatus were tested, they inhibited leukocyte migration to acetic acid-injured tissues [60, 61]. Recently, Jedinak et al. [62] showed that oyster mushroom concentrate (OMC) containing $\alpha$ - and $\beta$-glucans suppressed LPS-induced dependent activation of TNF- $\alpha$, IL-6, and IL-12 in RAW 264.7 murine macrophage cells, as well as inhibiting LPS-induced production of prostaglandin E2 (PGE2) and nitric oxide (NO). This was mainly attributed to the downregulation of COX-2 and iNOS expression, respectively. They also reported that OMC significantly suppressed LPS-induced production of TNF$\alpha$ in mice and concanavalin A-stimulated proliferation and secretion of INF- $\gamma$, IL-2, and IL-6 in mouse splenocytes [62].

The methanolic extract of Caripia montagnei (mainly polysaccharides of the glucan type) has also been shown to exert anti-inflammatory effects on male Swiss mice and male Wistar rats. The glucans significantly reduced the inflammatory infiltrate produced by thioglycolate-mediated peritonitis by about $75 \%$. Additionally, a significant reduction in the nitric oxide levels was observed in the exudates [63]. Ruthes et al. [64], meanwhile, investigated water and ethanolic extracts of $(1 \rightarrow 3),(1 \rightarrow 6)$ - $\beta$-D-glucans from the fruiting bodies of Lactarius rufus for their anti-inflammatory effects in both male and female Swiss mice. They found that soluble glucans inhibit inflammatory pain caused by formalin in comparison to the insoluble glucans, concluding that solubility and/or branching degree can alter the activity of $\beta$-glucans.

Furthermore, the aqueous extract of fucogalactan from Agaricus bisporus exhibited anti-inflammatory response in male Swiss mice [65]. It inhibited the neurogenic and inflammatory phases of formalin-induced licking, which they attributed to the decreased iNOS and COX-2 expression. Additionally, heterogalactans isolated by cold aqueous extraction from 


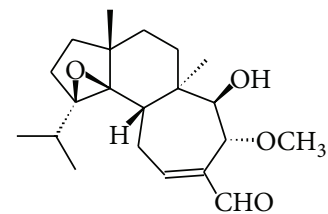

Cyathin 3

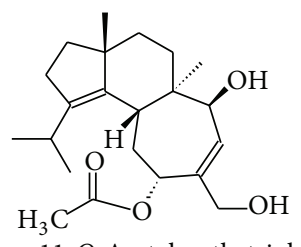

11-O-Acetylcyathatriol

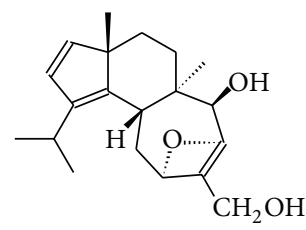

Erinacin I

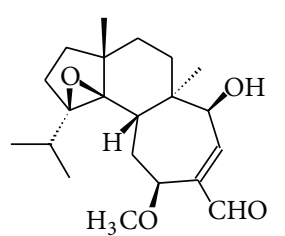

Cyathin 5

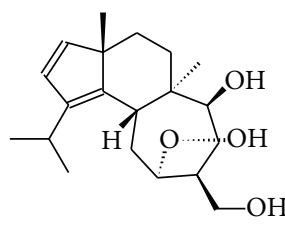

Cyathin 1

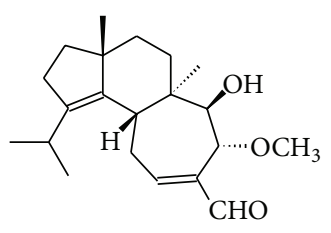

Neosarcodonin O

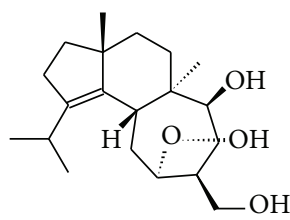

(12R)-11a,14a-Epoxy-13a,14b,15 trihydroxycyath-3-ene

FIGURE 2: Examples of some terpenoid bioactive compounds isolated from edible mushrooms.

Lentinus edodes have shown anti-inflammatory activities in male Swiss mice [66]. The active fraction was made of fucomannogalactan with a main chain of $(1 \rightarrow 6)$-linked $\alpha$ D-galactopyranosyl units, partially substituted at O-2 with single-unit $\beta$-D-Man $p$ or $\alpha$-L-Fuc $p$ side chains. The polysaccharide produced a marked effect against acetic acid induced visceral nociception and inhibited the peritoneal capillary permeability and leukocyte infiltration.

Mushroom polysaccharides with anti-inflammatory properties have been also reported in crude extracts of Lentinus polychrous, Termitomyces albuminosus, and Phellinus linteus. In L. polychrous, they inhibited NO and proinflammatory productions by downregulating the gene expressions of proinflammatory mediators, thereby decreasing paw oedema in rats [67]. In T. albuminosus, they decreased the acetic acid induced writhing response and the licking time in the late phase in the formalin test in male ICR mice [68]. Additionally, mouse ear swelling was inhibited by $61.8,79.0$, and $81.6 \%$ when the animals were treated with the dry matter of the culture broth $(1000 \mathrm{mg} / \mathrm{kg})$, crude saponin extract $(200 \mathrm{mg} / \mathrm{kg})$, or crude polysaccharide extract $(200 \mathrm{mg} / \mathrm{kg})$, respectively. In another study, polysaccharides of $P$. linteus inhibited the mouse ear oedema induced by croton oil, reduced the amount of writhing induced by acetic acid in mice [69], induced heme oxygenase-1 (HO-1) of the RAW 264.7 macrophages, and suppressed iNOS and the subsequent production of nitric oxide by downregulation of iNOS promoter activity in lipopolysaccharide-stimulated macrophages [70].

The polysaccharides of Pholiota nameko have been reported to inhibit topical oedema in mouse ears and significantly suppress the development of egg albumin-, carrageenan-, and formaldehyde-induced paw oedema in the animals, and, significantly, did not produce any gastric lesions in rats [71]. The polysaccharides of the golden needle mushroom (Flammulina velutipes) are composed of three monosaccharides (glucose, mannose, and xylose) in a molar ratio of $3.5: 0.8: 1.4$ and have been found to have anti-inflammatory activities and significantly decreased $\mathrm{CD} 4^{+} \mathrm{CD} 8^{+}$, ICAM-1, and MPO in both the serum and colon of normal and burned rats [72]. Tibetan mushroom polysaccharides also exhibited an anti-inflammatory activity by significantly inhibiting the formation of granuloma tissue by about $43 \%$ as well as significantly decreasing rat paw oedema induced by carrageenan [73]. Polysaccharides extracted from Cantharellus tubaeformis [74] and Lactarius flavidulus [75] have also been reported to exhibit anti-inflammatory properties. Table 2 summarizes some of the biological studies carried out with different compounds having anti-inflammatory activities isolated from mushrooms.

3.2. Terpenoids. Terpenes are the largest group of anti-inflammatory compounds in mushrooms and have been isolated from a range of different strains (Figure 2). Han et al. [76] isolated five novel cyathane diterpenes, identified as cyathins D$\mathrm{H}$ (1-5), in addition to three well known diterpenes, namely, neosarcodonin, cyathatriol, and 11-O-acetylcyathatriol from the ethylacetate extract of Cyathus africans. They found that cyathins D-H 3 and 5, as well as neosarcodonin and 11-Oacetylcyathatriol, showed potent inhibition activity against NO production in lipopolysaccharide-mouse monocyteactivated macrophage RAW 264.7, with $\mathrm{IC}_{50}$ values of 2.75, $1.47,12.0$, and $10.73 \mu \mathrm{M}$, respectively. Xu et al. [77] isolated three bioactive diterpenes from the ethylactetate extract of C. hookeri Berk, namely, cyathin, (12R)-11a,14a-epoxy13a,14b,15-trihydroxycyath-3-ene, and erinacine I. They also found that each of their three isolated diterpenes showed 
TABLE 2: Examples of biological studies performed with anti-inflammatory compounds from mushrooms.

\begin{tabular}{|c|c|c|c|}
\hline $\begin{array}{l}\text { Bioactive compound/ } \\
\text { mushroom species }\end{array}$ & Assay model & Results/mechanism of action & References \\
\hline \multicolumn{4}{|l|}{ Polysaccharides } \\
\hline Agaricus blazei & $\begin{array}{l}\text { (i) Mouse bone marrow-derived mast } \\
\text { cells (BMMCs) stimulated with PMA } \\
+ \text { A23187 }\end{array}$ & $\begin{array}{l}\text { (i) Inhibition of IL- } 6 \text { production, } \\
\text { downregulation of phosphorylation of Akt, } \\
\text { inhibition of } \beta \text {-hexosaminidase degranulation, } \\
\text { inhibition of prostaglandin } \mathrm{D}(2) \text {, and } \\
\text { leukotriene } \mathrm{C}(4) \text { production. }\end{array}$ & {$[51]$} \\
\hline \multirow{4}{*}{ Pleurotus pulmonarius } & $\begin{array}{l}\text { (i) Male Swiss mice (acetic acid } \\
\text { induced inflammation) }\end{array}$ & $\begin{array}{l}\text { (i) Dose-dependent anti-inflammatory } \\
\text { response, inhibition of leukocyte migration } \\
(82 \%), \mathrm{IC}_{50} \text { of } 1.19(0.74-1.92) \mathrm{mg} / \mathrm{kg}, 3 \mathrm{mg} / \mathrm{kg} \\
\text { i.p. glucan injection reduced } 85 \% \text { of writhes }\end{array}$ & {$[60]$} \\
\hline & $\begin{array}{l}\text { (ii) Mice ( } 3.5 \% \text { dextran sulfate sodium, } \\
\text { DSS in drinking water for } 14 \text { days, with } \\
20 \mathrm{mg} \text { fruiting body or mycelia } \\
\text { extract/mouse/day) }\end{array}$ & $\begin{array}{l}\text { (ii) Fruiting body and mycelia extracts } \\
\text { suppressed inflammatory reactions in vivo in } \\
\text { DSS induced colonic inflammation by } \\
\text { downregulating TNF- } \alpha \text { secretion and } \\
\text { inhibiting NF- } \kappa \text { B activation }\end{array}$ & {$[57,58]$} \\
\hline & $\begin{array}{l}\text { (iii) Acetic acid induced colitis in rats } \\
\text { ( } 2 \% \text { pleuran, or } 0.44 \% \text { hydrogel for } 4 \\
\text { weeks) }\end{array}$ & $\begin{array}{l}\text { (iii) Reduction in macroscopic damage score } \\
\text { by } 51 \text { and } 67 \% \text { for pleuran diet and hydrogel, } \\
\text { respectively; reduction in the activity of } \\
\text { myeloperoxidase and neutrophil infiltration }\end{array}$ & {$[61]$} \\
\hline & $\begin{array}{l}\text { (iv) Murine macrophage RAW } 264.7 \\
\text { cells, female Balb/C mice }\end{array}$ & $\begin{array}{l}\text { (iv) Suppression of LPS-induced dependent } \\
\text { activation of TNF- } \alpha \text {, IL- } 6 \text {, and IL-12, inhibition } \\
\text { of LPS-induced production of PGE2 and NO. } \\
\text { Suppression of LPS-induced production of } \\
\text { TNF- } \alpha \text { in mice and concanavalin A-stimulated } \\
\text { proliferation and secretion of INF- } \gamma \text {, IL-2, and } \\
\text { IL- } 6 \text { in mouse splenocytes }\end{array}$ & {$[62]$} \\
\hline Caripia montagnei & $\begin{array}{l}\text { (i) Male Swiss mice treated with } 10,30 \text {, } \\
\text { and } 50 \mathrm{mg} / \mathrm{kg} \text { with mushroom glucan }\end{array}$ & $\begin{array}{l}\text { (i) } 50 \mathrm{mg} / \mathrm{kg} \text { glucan reduced inflammatory } \\
\text { infiltrate produced by thioglycolate-induced } \\
\text { peritonitis by } 75.5 \% \text {, reduced NO level, IL-1ra, } \\
\text { IL-10, and IFN- } \gamma\end{array}$ & {$[63]$} \\
\hline Lactarius rufus & $\begin{array}{l}\text { (i) Swiss mice, formalin-induced } \\
\text { nociception, } 30 \mathrm{mg} / \mathrm{kg} \text { i.p. of fruiting } \\
\text { body extract (soluble, insoluble, and } \\
\text { modified) }\end{array}$ & $\begin{array}{l}\text { (i) Inhibition of neurogenic pain by } 36,47 \text {, and } \\
58 \% \text { for soluble, insoluble, and modified } \\
\text { glucans, respectively }\end{array}$ & {$[64]$} \\
\hline A. bisporus & $\begin{array}{l}\text { (i) Male Swiss mice, formalin-induced } \\
\text { licking }\end{array}$ & $\begin{array}{l}\text { (i) Inhibition of neurogenic and inflammatory } \\
\text { phases, antinociceptive effect with } \mathrm{IC}_{50} \text { of } 36.0 \\
(25.8-50.3 \mathrm{mg} / \mathrm{kg}) \\
\text { (ii) Decreased iNOS and COX2 }\end{array}$ & {$[65]$} \\
\hline Lentinus edodes & $\begin{array}{l}\text { (i) Male Swiss mice, acetic acid } \\
\text { induced inflammation, } 3-100 \mathrm{mg} / \mathrm{kg} \\
\text { i.p. fruiting body concentrate }\end{array}$ & $\begin{array}{l}\text { (i) Inhibition of induced nociception with } \mathrm{IC}_{50} \\
\text { of } 13.8(7.8-23.5) \mathrm{mg} / \mathrm{kg}, 97 \% \text { inhibition at } \\
100 \mathrm{mg} / \mathrm{kg} \\
\text { (ii) Inhibition of peritoneal capillary } \\
\text { permeability and leukocyte infiltration }(76 \% \\
\text { inhibition), } \mathrm{IC}_{50} 13.9,8.2-23.7 \text {, and } 100 \% \\
\text { inhibition, } \mathrm{IC}_{50} 6.5,1.5-28.2 \mathrm{mg} / \mathrm{kg} \text {, } \\
\text { respectively }\end{array}$ & {$[66]$} \\
\hline L. polychrous & $\begin{array}{l}\text { (i) Carrageenan-induced paw edema } \\
\text { in male Sprague-Dawley rats, murine } \\
\text { macrophage RAW } 264.7 \text { cells }\end{array}$ & $\begin{array}{l}\text { (i) Dose-dependent inhibition of NO, } \\
\text { intracellular } \mathrm{O}_{2}^{-} \text {production } \\
\text { (ii) Decreased expression of iNOS, IL- } 1 \beta \text {, IL- } 6 \text {, } \\
\text { TNF- } \alpha \text {, and COX- } 2\end{array}$ & {$[67]$} \\
\hline
\end{tabular}


TABLE 2: Continued.

\begin{tabular}{|c|c|c|c|}
\hline $\begin{array}{l}\text { Bioactive compound/ } \\
\text { mushroom species }\end{array}$ & Assay model & Results/mechanism of action & References \\
\hline Termitomyces albuminosus & $\begin{array}{l}\text { (i) Acetic acid induced writhing in } \\
\text { male ICR mice, formalin test, xylene, } \\
\text { and carrageenan induced ear edema }\end{array}$ & $\begin{array}{l}\text { (i) Inhibition of ear swelling by } 61.8,79.0 \text {, and } \\
81.6 \% \text { for treatment with dry matter of the } \\
\text { culture broth }(1000 \mathrm{mg} / \mathrm{kg}) \text {, crude saponin } \\
\text { extract }(200 \mathrm{mg} / \mathrm{kg}) \text {, or crude polysaccharide } \\
\text { extract }(200 \mathrm{mg} / \mathrm{kg}) \text {, respectively }\end{array}$ & {$[68]$} \\
\hline Phellinus linteus & $\begin{array}{l}\text { (i) Croton oil induced ear edema and } \\
\text { acetic acid induced writhing in male } \\
\text { ICR mice }\end{array}$ & $\begin{array}{l}\text { (i) Extract treatment with } 1 \mathrm{mg} / \text { ear gave } 45 \text { and } \\
41.5 \% \text { inhibition in ear plug weight and } \\
\text { thickness, respectively, oral administration of } \\
\text { extract }(100-400 \mathrm{mg} / \mathrm{kg}) \text { inhibited writhing } \\
\text { number }(35.9-68.9 \%)\end{array}$ & [69] \\
\hline Pholiota nameko & $\begin{array}{l}\text { (i) Xylene induced ear edema, adult } \\
\text { Swiss mice and Sprague-Dawley rats, } \\
\text { formaldehyde, egg albumin, and } \\
\text { carrageenan induced paw edema in } \\
\text { rats and mice }\end{array}$ & $\begin{array}{l}\text { (i) Extract ( } 5 \mathrm{mg} / \text { ear) inhibited ear edema, } \\
\text { suppression of egg albumin, carrageenan and } \\
\text { formaldehyde-induced paw edema at } \\
100-400 \mathrm{mg} / \mathrm{kg} \text { i.p., } 10.96-43.75 \% \text { inhibition of } \\
\text { granuloma tissue growth, no production of } \\
\text { gastric lesions in rats }\end{array}$ & [71] \\
\hline Flammulina velutipes & $\begin{array}{l}\text { (i) Male Wistar rats, fed } \\
100-300 \mathrm{mg} / \mathrm{kg} \text { mushroom for } 30 \text { days }\end{array}$ & $\begin{array}{l}\text { (i) Decreased levels of } \mathrm{CD} 4^{+} \mathrm{CD} 8^{+}, \mathrm{MPO} \text {, and } \\
\text { ICAM-1, with increased level in IL-10 in serum }\end{array}$ & {$[72]$} \\
\hline
\end{tabular}

Terpenoids

Cyathus africanus

C. hookeri (i) Mouse monocyte-macrophage RAW 264.7 cells, NO assay

(i) Mouse monocyte-macrophage RAW 264.7 cells, $\mathrm{NO}$ assay

(i) LPS-stimulated murine macrophage RAW 264.7 cells, NO assay

Ganoderma lucidum

\section{Inonotus obliquus}

(ii) Acetic acid induced ear edema in female ICR and SENCAR mice (i) Cyathins D-H 3 and 5, neosarcodonin, and 11-O-acetylcyatha-triol inhibited NO production with an $\mathrm{IC}_{50}$ value of $2.75,1.47,12.0$, and $10.73 \mu \mathrm{M}$, respectively

(i) Inhibition of $\mathrm{NO}$ production with an $\mathrm{IC}_{50}$ of $15.5,52.3$, and $16.8 \mu \mathrm{M}$, respectively.

(i) Inhibition of TNF- $\alpha$, IL-6, NO, and PGE2, downregulation of iNOS and COX-2, inhibition of NF- $\kappa \mathrm{B}$, decreased NF- $\kappa \mathrm{B}-\mathrm{DNA}$ binding activity, and suppression of $\mathrm{p} 65$ phosphorylation

(ii) Significant inhibition of inflammation $(1 \mu \mathrm{g} /$ ear $)$ in mice with $\mathrm{IC}_{50}$ values between 0.07 and $0.39 \mathrm{mg} / \mathrm{ear}$, with inhibition ratio ranging from 58 to $97 \%$

(i) Reduced nitrate levels by an average of $50 \%$, dose-dependent inhibition of IL- $1 \beta$, IL- 6 , and TNF $\alpha$

(ii) Trametenolic acid, ergosterol peroxide, $3 \beta$-hydroxy-8,24-dien-21-al, ergosterol and inotodiol inhibited NO production, and NF- $\kappa \mathrm{B}$ luciferase activity, with an inhibition percentage of 50.04, 36.88, 20.36, 6.00, and $3.13 \%$, respectively

(iii) Methanolic extract inhibited production of NO, prostaglandin $\mathrm{E}_{2}$, and TNF- $\alpha$, inhibition of mRNA expression of iNOS and COX-2 (i) Murine macrophage RAW 164.7 cells 
TABLE 2: Continued.

\begin{tabular}{|c|c|c|c|}
\hline $\begin{array}{l}\text { Bioactive compound/ } \\
\text { mushroom species }\end{array}$ & Assay model & Results/mechanism of action & References \\
\hline \multicolumn{4}{|l|}{ Peptides } \\
\hline Cordyceps sinensis & $\begin{array}{l}\text { (i) Acetic acid induced inflammation } \\
\text { in mice }\end{array}$ & $\begin{array}{l}\text { (i) Decreased level of TNF- } \alpha \text {, IL- } 1 \beta \text {, } \\
\text { dose-dependent inhibition of abdominal } \\
\text { constrictions }\end{array}$ & {$[86]$} \\
\hline \multicolumn{4}{|l|}{ Phenolics } \\
\hline Lactarius deliciosus & $\begin{array}{l}\text { (i) LPS-stimulated RAW } 364.7 \\
\text { macrophage cells, nitrite, and cytokine } \\
\text { assays }\end{array}$ & $\begin{array}{l}\text { (i) } 0.5 \mathrm{mg} / \mathrm{mL} \text { mushroom extract inhibited NO } \\
\text { production and expression of iNOS, IL- } 1 \beta \text {, and } \\
\text { IL6 mRNAs }\end{array}$ & [91] \\
\hline Daldinia childiae & $\begin{array}{l}\text { (i) LPS-stimulated RAW } 264.7 \\
\text { macrophage cells }\end{array}$ & $\begin{array}{l}\text { (i) Daldinals suppressed NO production with } \\
\text { IC }_{50} \text { values ranging between } 4.6 \text { and } 15.2 \mu \mathrm{M} \\
\text { and inhibited iNOS mRNA synthesis }\end{array}$ & {$[72]$} \\
\hline Albatrellus caeruleoporus & $\begin{array}{l}\text { (i) LPS-stimulated mouse macrophage } \\
\text { RAW } 264.7 \text { cells }\end{array}$ & $\begin{array}{l}\text { (i) Grifolins inhibited NO production with } \\
\text { IC }_{50} \text { values ranging between } 22.9 \text { and } 29 \mu \mathrm{M}\end{array}$ & {$[94]$} \\
\hline \multicolumn{4}{|c|}{ Syringaldehyde and syringic acid } \\
\hline Elaphomyces granulates & $\begin{array}{l}\text { (i) Mouse macrophage RAW } 264.7 \\
\text { cells }\end{array}$ & $\begin{array}{l}\text { (i) Crude ethanolic extract }(50 \mu \mathrm{g} / \mathrm{mL}) \\
\text { inhibited COX- } 2 \text { activity by } 68 \% \text {, purified } \\
\text { syringaldehyde, and syringic acid inhibited } \\
\text { COX-2 activity in a dose-dependent manner, } \\
\text { with an } \mathrm{IC}_{50} \text { of } 3.5 \text { and } 0.4 \mu \mathrm{g} / \mathrm{mL} \text {, respectively }\end{array}$ & {$[96]$} \\
\hline \multicolumn{4}{|l|}{ Agaricoglycerides } \\
\hline Grifola frondosa & $\begin{array}{l}\text { (i) Acetic acid- and formalin-induced } \\
\text { inflammation in Wister rats, treatment } \\
\text { with orally fed extracts } \\
(100-500 \mathrm{mg} / \mathrm{kg} / \text { day })\end{array}$ & $\begin{array}{l}\text { (i) } 500 \mathrm{mg} / \mathrm{kg} / \mathrm{day} \text { inhibited induced } \\
\text { upregulation of NF- } \kappa \mathrm{B} \text { and the production of } \\
\text { IL- } 1 \beta \text {, TNF- } \alpha \text {, ICAM- } 1 \text {, COX- } 2 \text {, and iNOS, } \\
\text { suppressed acetic acid induced abdominal } \\
\text { constrictions and formalin-induced } \\
\text { spontaneous nociceptive behavior }\end{array}$ & [97] \\
\hline
\end{tabular}

potent anti-inflammatory activities, inhibiting NO production in mouse monocyte-macrophages RAW 264.7, with an $\mathrm{IC}_{50}$ of $15.5,52.3$, and $16.8 \mu \mathrm{M}$, respectively.

Another class of terpenoids (triterpenes) have also been shown to exhibit high anti-inflammatory properties [78]. The authors of this study evaluated the anti-inflammatory effects of triterpene extract of Ganoderma lucidum in lipopolysaccharide- (LPS-) stimulated macrophages. They reported that the triterpene extract significantly suppressed the secretion of inflammatory cytokine tumour necrosis factor- $\alpha$ (TNF- $\alpha$ ) and interleukin-6 (IL-6), as well as the inflammatory mediators nitric oxide (NO) and prostaglandin E2 (PGE2), from LPS-stimulated murine RAW 264.7 cells. Additionally, the LPS-dependent expression of inducible nitric oxide synthase (iNOS) and cyclooxygenase 2 (COX2) in RAW 264.7 cells were downregulated. The anti-inflammatory effects of the triterpene extract have been attributed to the inhibition of transcription factor NF- $\kappa \mathrm{B}$, as observed in the decreased NF- $\kappa$ B-DNA binding activity, as well as the suppression of p65 phosphorylation in the treated LPSstimulated macrophages. Additionally, the extract inhibited LPS-dependent AP-1-DNA binding activity and downregulated the expression of AP-1 subunit c-Jun. Furthermore, the activity of MAP kinases has been suppressed, as observed by the downregulation of LPS-induced phosphorylation of ERK1/2 and JNK.
Furthermore, different lanostane-type triterpenic acids with potent anti-inflammatory properties have been isolated from G. lucidum $[79,80]$. Akihisa et al. [81] reported that nine lucidenic acids and four ganoderic acids (Figure 3), isolated from the fruiting bodies of G. lucidum, significantly inhibited 12-O-tetradecanoylphorbol-13-acetate induced inflammation $(1 \mu \mathrm{g} /$ ear $)$ in mice, with $\mathrm{IC}_{50}$ values between 0.07 and $0.39 \mathrm{mg} / \mathrm{ear}$.

Different sterols (Figure 4) with potent anti-inflammatory activities have been also isolated and purified from the edible mushroom Inonotus obliquus. These significantly inhibited the levels of IL- $1 \beta$, IL- 6 , and TNF $\alpha$ in a dose-dependent manner in murine macrophage RAW 164.7 cells [82]. Additionally, Park et al. [83] found that the methanolic extract of $I$. obliquus significantly inhibited NO production, prostaglandin $\mathrm{E}_{2}$, and TNF- $\alpha$ in LPS-stimulated RAW 264.7 macrophages. Ma et al. [84] isolated and identified six known triterpenes from the sclerotia of $I$. obliquus. They reported that trametenolic acid, ergosterol peroxide, $3 \beta$-hydroxy-8,24dien-21-al, ergosterol, and inotodiol inhibited NO production and NF- $\kappa$ B luciferase activity in macrophage RAW 264.7 cells, with an inhibition percentage of 50.04, 36.88, 20.36, 6.00 , and $3.13 \%$, respectively.

3.3. Peptides. In addition to the previous bioactive compounds, anti-inflammatory peptides of different molecular 


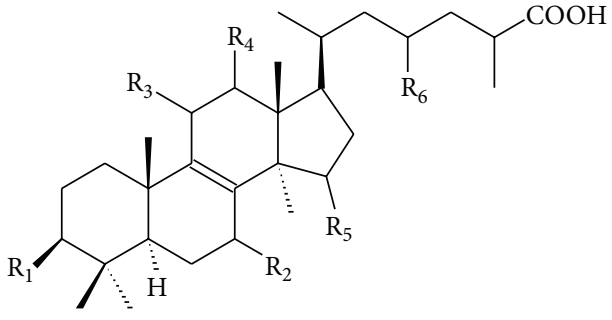

Ganoderic acids

$$
\begin{aligned}
& \text { A: } \mathrm{R}_{1}=\mathrm{R}_{3}=\mathrm{R}_{6}=\mathrm{O}, \mathrm{R}_{2}=\mathrm{R}_{5}=\beta-\mathrm{OH}, \mathrm{R}_{4}=\mathrm{H} \\
& \text { B: } \mathrm{R}_{1}=\mathrm{R}_{3}=\mathrm{R}_{5}=\mathrm{R}_{6}=\mathrm{O}, \mathrm{R}_{2}=\beta-\mathrm{OH}, \mathrm{R}_{4}=\mathrm{H} \\
& \mathrm{D}: \mathrm{R}_{1}=\mathrm{R}_{3}=\mathrm{R}_{5}=\mathrm{R}_{6}=\mathrm{O}, \mathrm{R}_{2}=\mathrm{R}_{4}=\beta-\mathrm{OH}, \\
& \mathrm{F}: \mathrm{R}_{1}=\mathrm{R}_{2}=\mathrm{R}_{3}=\mathrm{R}_{5}=\mathrm{R}_{6}=\mathrm{O}, \mathrm{R}_{4}=\beta-\mathrm{OH}, \\
& \text { G: } \mathrm{R}_{1}=\mathrm{R}_{2}=\mathrm{R}_{4}=\beta-\mathrm{OH}, \mathrm{R}_{3}=\mathrm{R}_{5}=\mathrm{R}_{6}=\mathrm{O}, \\
& \mathrm{H}: \mathrm{R}_{1}=\beta-\mathrm{OH}, \mathrm{R}_{2}=\mathrm{R}_{3}=\mathrm{R}_{5}=\mathrm{R}_{6}=\mathrm{O}, \mathrm{R}_{4}=\beta-\mathrm{OAC} \\
& \text { Z: } \mathrm{R}_{1}=\beta-\mathrm{OH}, \mathrm{R}_{2}=\mathrm{R}_{3}=\mathrm{R}_{4}=\mathrm{R}_{5}=\mathrm{R}_{6}=\mathrm{H}
\end{aligned}
$$

FIGURE 3: Structures of different ganoderic acids and derivative isolated from G. lucidum.<smiles>CC(CCC(O)C(C)(O)CO)C1CCC2C3=CCC4C(C)(C)C(=O)CCC4(C)C3=CCC21C</smiles>

Ganodermanotriol<smiles>CC(C)=CCCC(C)C1CCC2C3=C4CCC5(CCC(O)C(C)(C)C5CCC43C)CCC21C</smiles>

HO<smiles>CC(C)=CCCC(C)C1CCC2C3=CCC4C(CCO)C3(C)CCCC4(C)C2(C)CCC1O</smiles>
$\mathrm{HO}$<smiles>CC(C)=CCC(O)C(C)C1CCC2C3=C(CCC21)C1(C)CCC(O)C(C)(C)C1CC3</smiles>

$\mathrm{HO}$<smiles>CC(C)=CCCC(C(=O)O)C1CCC2C3=C(CCC21)C1(C)CCC(O)C(C)(C)C1CC3</smiles>

FIGURE 4: Structures of different sterol compounds isolated from I. obliquus.

weights have been isolated from mushrooms. Cordymin, a low molecular weight peptide $(10,906 \mathrm{Da})$, has been purified from the medicinal mushroom Cordyceps sinensis [85, 86] and from C. militaris [87]. This peptide significantly inhibited the infiltration of polymorphonuclear cells and IRinduced upregulation of C3 protein produced in the brain, interleukin- $1 \beta$, and tumour necrosis factor- $\alpha$, which had a neuroprotective effect on the ischemic brain, due to the inhibition of inflammation. Agrocybin represents another peptide isolated from the edible mushroom Agrocybe cylindracea. Agrocybin exhibited antifungal activity against $\mathrm{Myco}-$ sphaerella arachidicola, with an $\mathrm{IC}_{50}$ value of $125 \mu \mathrm{M}$ at different temperatures up to $80^{\circ} \mathrm{C}$ [88].

3.4. Phenolics. Many edible mushrooms have been found to exhibit anti-inflammatory properties due to the presence of some phenolic compounds (Figure 5). For example, the common phenolic molecule pyrogallol has been extracted from 
<smiles>COc1cc(O)cc(C(=O)c2cc(C)cc(OC)c2OC)c1C=O</smiles>

(a)<smiles>Oc1cccc(O)c1O</smiles>

(b)

Figure 5: Chemical structures of (a) daldinal and (b) pyrogallol.

Syringaldehyde<smiles>CC(C)=CCC/C(C)=C/CC/C(C)=C/Cc1c(O)cc(C)cc1O</smiles>

Neogrifolin<smiles>CC(C)=CCC/C(C)=C/CC/C(C)=C/Cc1c(C)cc(O)cc1O</smiles>

Grifolinone A<smiles>CC(C)=CC(=O)C/C(C)=C/CC/C(C)=C/Cc1c(O)cc(C)cc1O</smiles><smiles>CC(C)=CCCCCCCCCCCCCCC=CC1=C(C)C(=O)C(O)=C(C(C)C=C(C)CC(C)C=C(C)CC(=O)C=C(C)C)C1</smiles>

FIGURE 6: Grifolin and neogrifolins isolated from Albatrellus mushrooms.

Agaricus bisporus, Cantharellus cibarius, and Lactarius deliciosus [89, 90]. Pyrogallol inhibited NO production and iNOS, IL-1 $\beta$, and IL6 mRNAs expression in response to LPSstimulated RAW 364.7 macrophages [91]. Additionally, daldinals have been purified from Daldinia childiae. They strongly suppressed the LPS-induced production of NO in RAW 264.7 cells, with $\mathrm{IC}_{50}$ values ranging between 4.6 and $15.2 \mu \mathrm{M}$ depending on the derivative [92]. This effect was attributed to the inhibition of iNOS mRNA synthesis.

Grifolin and grifolin derivatives (Figure 6) represent another class of farnesyl phenolic compounds which have been isolated from the edible mushroom Albatrellus ovinus and which exhibit anti-inflammatory properties [93]. Grifolins showed significant inhibition of NO production stimulated by LPS in RAW 264.7 cells, with $\mathrm{IC}_{50}$ values ranging between 22.9 and $29 \mu \mathrm{M}$ [94], as well as inhibiting histamine release from rat peritoneal mast cells [95].<smiles>COc1cc(C=O)cc(OC)c1O</smiles>

Syringaldehyde<smiles>COc1cc(C(=O)O)cc(OC)c1O</smiles>

Syringic acid
FIGURE 7: Structure of anti-inflammatory compounds isolated from edible truffles.

3.5. Miscellaneous. The ectomycorrhizal edible truffle Elaphomyces granulatus has been evaluated for its anti-inflammatory effects. The $95 \%$ ethanolic extract of the fruiting bodies contained two active aromatic compounds with antiinflammatory and antioxidant activities, namely, syringaldehyde and syringic acid (Figure 7). The anti-inflammatory 
properties of these two low molecular weight organic compounds were proven by their inhibition of the mediator cyclooxygenase-2 (COX-2) enzyme in mouse macrophage (RAW 264.7). The crude ethanolic extract caused about $68 \%$ inhibition of the enzyme activity at a concentration of $50 \mu \mathrm{g} / \mathrm{mL}$. The inhibitory effect of the purified syringaldehyde and syringic acid on COX-2 activity showed a dosedependent effect, with an $\mathrm{IC}_{50}$ of 3.5 and $0.4 \mu \mathrm{g} / \mathrm{mL}$, respectively, $[19,96]$.

Agaricoglycerides represent a new class of fungal secondary metabolites that constitute esters of chlorinated 4hydroxy benzoic acid and glycerol and are produced in the culture of different edible mushrooms such as Grifola frondosa and Agaricus macrosporus. They also exhibited significant anti-inflammatory activity. The agaricoglycerides isolated from Grifola frondosa (AGF) showed potent antiinflammatory activity since they were able to reduce the level of many mediators, such as IL- $1 \beta, \mathrm{NF}-\kappa \mathrm{B}$, ICAM- 1 , COX2 , and iNOS in animal models [97]. This study showed that an oral dose of $500 \mathrm{mg} / \mathrm{kg} /$ day of the ethanolic extract of an agaricoglyceride mixture showed strong anti-inflammatory activity in a Wister rat animal model.

\section{Future Perspectives}

This review has demonstrated the importance of mushrooms as potential biofactories for the production of natural antiinflammatory metabolites of highly diversified chemical structure. The bioactivities of these compounds are exhibited through the downregulation of different types of inflammatory mediators. In addition to the high potential application of anti-inflammatory metabolites from mushrooms in forms of unpurified extract and extra pure compounds in medical applications, they can also be used in cosmeceutical products as safe and natural active ingredients without undesired side effects. However, the future medical application of antiinflammatory compounds isolated from mushrooms faces five main challenges. Firstly, most of the studied mushrooms are not cultivable in greenhouses, and thus their availability is both seasonal and highly affected by changes in the weather. Secondly, the contents of the bioactive ingredients vary widely between samples, dependent on the collection time and procedure, the season, and the environment. Thirdly, mushroom cultivation in greenhouses is an open system and is not run according to the current Good Manufacturing Practice (cGMP) requirements for the production of bioactive medicinal compounds. Therefore, more research should be done on the development of mushroom cultivation processes in submerged cultures under fully sterile conditions so as to produce bioactive metabolites for pharmaceutical applications. Fourthly, in most of the studies conducted so far, the anti-inflammatory activities of mushrooms were demonstrated using crude mushroom extracts or solvent extracts of different metabolites in a mixed form. It is necessary, therefore, to isolate and identify the active metabolites for a better understanding of the anti-inflammatory properties of each particular compound and the possible side effects, if any. This step is necessary to upgrade the crude extract from a nutraceutical to pharmaceutical market after proper product formulation and clinical trials to determine the proper dose and claims. Fifthly, there is a lack of validated standard testing protocols to guarantee the quality and the efficacy of mushroom products for pharmaceutical applications. Overall, therefore, more research is required to overcome the challenges mentioned above before macrofungi can be fully accepted as one of the major biofactories for the production of anti-inflammatory medicine.

\section{Conflict of Interests}

The authors declare that there is no conflict of interests regarding the publication of this paper.

\section{Acknowledgments}

The authors extend their appreciation to the Deanship of Scientific Research at King Saud University for funding the work through the Research Group Project no. RGP-VPP-284. The authors are also thankful for Research Management Centre, Universiti Teknologi Malaysia.

\section{References}

[1] W. E. Smalley, W. A. Ray, J. R. Daugherty, and M. R. Griffin, "Nonsteroidal anti-inflammatory drugs and the incidence of hospitalizations for peptic ulcer disease in elderly persons," American Journal of Epidemiology, vol. 141, no. 6, pp. 539-545, 1995.

[2] M. Sinha, L. Gautam, P. K. Shukla, P. Kaur, S. Sharma, and T. P. Singh, "Current perspectives in NSAID-induced gastropathy," Mediators of Inflammation, vol. 2013, Article ID 258209, 11 pages, 2013.

[3] C. E. Dugowson and P. Gnanashanmugam, "Nonsteroidal antiinflammatory drugs," Physical Medicine and Rehabilitation Clinics of North America, vol. 17, no. 2, pp. 347-354, 2006.

[4] E. L. Fosbøl, G. H. Gislason, S. Jacobsen et al., "Risk of myocardial infarction and death associated with the use of nonsteroidal anti-inflammatory drugs (NSAIDs) among healthy individuals: a nationwide cohort study," Clinical Pharmacology \& Therapeutics, vol. 85, no. 2, pp. 190-197, 2009.

[5] I. L. Meek, M. A. F. J. van de Laar, and H. E. Vonkeman, "Nonsteroidal anti-inflammatory drugs: an overview of cardiovascular risks," Pharmaceuticals, vol. 3, no. 7, pp. 2146-2162, 2010.

[6] G. Yuan, M. L. Wahlqvist, G. He, M. Yang, and D. Li, "Natural products and anti-inflammatory activity," Asia Pacific Journal of Clinical Nutrition, vol. 15, no. 2, pp. 143-152, 2006.

[7] R. de Cássia da Silveira E Sá, L. N. Andrade, and D. P. de Sousa, "A review on anti-inflammatory activity of monoterpenes," Molecules, vol. 18, no. 1, pp. 1227-1254, 2013.

[8] Y. Bellik, L. Boukraâ, H. A. Alzahrani et al., "Molecular mechanism underlying anti-inflammatory and anti-Allergic activities of phytochemicals: an update," Molecules, vol. 18, no. 1, pp. 322353, 2013.

[9] A. Gomes, E. Fernandes, J. L. F. C. Lima, L. Mira, and M. L. Corvo, "Molecular mechanisms of anti-inflammatory activity mediated by flavonoids," Current Medicinal Chemistry, vol. 15, no. 16, pp. 1586-1605, 2008.

[10] S. S. Mendes, R. R. Bomfim, H. C. R. Jesus et al., "Evaluation of the analgesic and anti-inflammatory effects of the essential oil of Lippia gracilis leaves," Journal of Ethnopharmacology, vol. 129, no. 3, pp. 391-397, 2010. 
[11] M. G. Miguel, "Antioxidant and anti-inflammatory activities of essential oils: a short review," Molecules, vol. 15, no. 12, pp. $9252-$ 9287, 2010.

[12] O. V. Oyetayo, "Medicinal uses of mushrooms in Nigeria: towards full and sustainable exploitation," African Journal of Traditional, Complementary and Alternative Medicines, vol. 8, no. 3, pp. 267-274, 2011.

[13] D. D. Tibuhwa, "Folk taxonomy and use of mushrooms in communities around Ngorongoro and Serengeti National Park, Tanzania," Journal of Ethnobiology and Ethnomedicine, vol. 8, article 36, 2012.

[14] H. El Enshasy, E. A. Elsayed, R. Aziz, and M. A. Wadaan, "Mushrooms and truffles: historical biofactories for complementary medicine in Africa and in the middle East," Evidence-Based Complementary and Alternative Medicine, vol. 2013, Article ID 620451, 10 pages, 2013.

[15] J. M. Trappe, A. W. Claridge, D. L. Claridge, and L. Liddle, "Desert truffles of the Australian outback: ecology, ethnomycology, and taxonomy," Economic Botany, vol. 62, no. 3, pp. 497$506,2008$.

[16] S. Badalyan, "Medicinal aspects of edible ectomycorrhizal mushrooms," in Edible Ectomycorrhizal Mushrooms, pp. 317334, Springer, Berlin, Germany, 2012.

[17] A. Colak, F. Özlem, and E. Sesli, "Nutritional composition of some wild edible mushrooms," Turkish Journal of Biochemistry, vol. 34, no. 1, pp. 25-31, 2009.

[18] P. Kalač, "A review of chemical composition and nutritional value of wild-growing and cultivated mushrooms," Journal of the Science of Food and Agriculture, vol. 93, no. 2, pp. 209-218, 2013.

[19] S. Wang and M. F. Marcone, “The biochemistry and biological properties of the world's most expensive underground edible mushroom: truffles," Food Research International, vol. 44, no. 9, pp. 2567-2581, 2011.

[20] A. Villares, A. García-Lafuente, E. Guillamón, and Á. Ramos, "Identification and quantification of ergosterol and phenolic compounds occurring in Tuber spp. truffles," Journal of Food Composition and Analysis, vol. 26, no. 1-2, pp. 177-182, 2012.

[21] J.-Z. He, Q.-M. Ru, D.-D. Dong, and P.-L. Sun, "Chemical characteristics and antioxidant properties of crude water soluble polysaccharides from four common edible mushrooms," Molecules, vol. 17, no. 4, pp. 4373-4387, 2012.

[22] H. El Enshasy, "Immunomodulators," in The Mycota: Industrial Applications, vol. 10, pp. 165-194, Springer, Berlin, Germany, 2010.

[23] D. Yamanaka, R. Tada, Y. Adachi et al., "Agaricus brasiliensisderived $\beta$-glucans exert immunoenhancing effects via a dectin1-dependent pathway," International Immunopharmacology, vol. 14, no. 3, pp. 311-319, 2012.

[24] X.-Q. Han, X.-M. Wu, X.-Y. Chai et al., "Isolation, characterization and immunological activity of a polysaccharide from the fruit bodies of an edible mushroom, Sarcodon aspratus (Berk.) S. Ito," Food Research International, vol. 44, no. 1, pp. 489-493, 2011.

[25] H. A. El Enshasy and R. Hatti-Kaul, "Mushroom immunomodulators: unique molecules with unlimited applications," Trends in Biotechnology, vol. 31, no. 12, pp. 668-677, 2013.

[26] D. Sliva, J. Loganathan, J. Jiang et al., "Mushroom Ganoderma lucidum prevents colitis-associated carcinogenesis in mice," PLoS ONE, vol. 7, no. 10, Article ID e47873, 2012.
[27] A. Zong, H. Cao, and F. Wang, "Anticancer polysaccharides from natural resources: a review of recent research," Carbohydrate Polymers, vol. 90, no. 4, pp. 395-410, 2012.

[28] M.-F. Moradali, H. Mostafavi, S. Ghods, and G.-A. Hedjaroude, "Immunomodulating and anticancer agents in the realm of macromycetes fungi (macrofungi)," International Immunopharmacology, vol. 7, no. 6, pp. 701-724, 2007.

[29] Y.-J. Liu, J. Shen, Y.-M. Xia, J. Zhang, and H.-S. Park, "The polysaccharides from Ganoderma lucidum: are they always inhibitors on human hepatocarcinoma cells?" Carbohydrate Polymers, vol. 90, no. 3, pp. 1210-1215, 2012.

[30] H. El-Enshasy, A. Daba, M. El-Demellawy, A. Ibrahim, S. El Sayed, and I. El-Badry, "Bioprocess development for large scale production of anticancer exo-polysaccharide by Pleurotus ostreatus in submerged culture," Journal of Applied Sciences, vol. 10, no. 21, pp. 2523-2529, 2010.

[31] S. Janakat, S. Al-Fakhiri, and A.-K. Sallal, "A promising peptide antibiotic from Terfezia claveryi aqueous extract against Staphylococcus aureusin vitro," Phytotherapy Research, vol. 18, no. 10, pp. 810-813, 2004.

[32] S. M. Janakat, S. M. Al-Fakhiri, and A.-K. J. Sallal, "Evaluation of antibacterial activity of aqueous and methanolic extracts of the truffle Terfezia claveryi against Pseudomonas aeruginosa," Saudi Medical Journal, vol. 26, no. 6, pp. 952-955, 2005.

[33] G. Adotey, A. Quarcoo, J. C. Holliday, S. Fofie, and B. Saaka, "Effect of immunomodulating and antiviral agent of medicinal mushrooms (immune assist 24/7) on CD4+ T-Lymphocyte Counts of HIV-infected patients," International Journal of Medicinal Mushrooms, vol. 13, no. 2, pp. 109-113, 2011.

[34] J.-Y. Yeh, L.-H. Hsieh, K.-T. Wu, and C.-F. Tsai, "Antioxidant properties and antioxidant compounds of various extracts from the edible basidiomycete Grifola frondosa (Maitake)," Molecules, vol. 16, no. 4, pp. 3197-3211, 2011.

[35] Z. Wang and D. Luo, "Antioxidant activities of different fractions of polysaccharide purified from Gynostemma pentaphyllum Makino," Carbohydrate Polymers, vol. 68, no. 1, pp. 54-58, 2007.

[36] K. N. Yoon, N. Alam, K. R. Lee et al., "Antioxidant and antityrosinase activities of various extracts from the fruiting bodies of Lentinus lepideus," Molecules, vol. 16, no. 3, pp. 2334-2347, 2011.

[37] H. Mu, A. Zhang, W. Zhang, G. Cui, S. Wang, and J. Duan, "Antioxidative properties of crude polysaccharides from Inonotus obliquus," International Journal of Molecular Sciences, vol. 13, no. 7, pp. 9194-9206, 2012.

[38] S.-H. Hu, J.-C. Wang, J.-L. Lien, E.-T. Liaw, and M.-Y. Lee, “Antihyperglycemic effect of polysaccharide from fermented broth of Pleurotus citrinopileatus," Applied Microbiology and Biotechnology, vol. 70, no. 1, pp. 107-113, 2006.

[39] A.-H. Kwon, Z. Qiu, M. Hashimoto, K. Yamamoto, and T. Kimura, "Effects of medicinal mushroom (Sparassis crispa) on wound healing in streptozotocin-induced diabetic rats," The American Journal of Surgery, vol. 197, no. 4, pp. 503-509, 2009.

[40] H. C. Lo and S. P. Wasser, "Medicinal mushrooms for glycemic control in diabetes mellitus: History, current status, future perspectives, and unsolved problems (review)," International Journal of Medicinal Mushrooms, vol. 13, no. 5, pp. 401-426, 2011.

[41] E. Guillamón, A. García-Lafuente, M. Lozano et al., "Edible mushrooms: role in the prevention of cardiovascular diseases," Fitoterapia, vol. 81, no. 7, pp. 715-723, 2010.

[42] C. Nathan, "Points of control in inflammation," Nature, vol. 420, no. 6917, pp. 846-852, 2002. 
[43] J. M. Cook-Mills and T. L. Deem, "Active participation of endothelial cells in inflammation," Journal of Leukocyte Biology, vol. 77, no. 4, pp. 487-495, 2005.

[44] T. B. Levine and A. B. Levine, "Inflammation," in Metabolic Syndrome and Cardiovascular Disease, pp. 192-227, Blackwell Publishing, Oxford, UK, 2012.

[45] L. M. Coussens and Z. Werb, "Inflammation and cancer," Nature, vol. 420, no. 6917, pp. 860-867, 2002.

[46] A. Mantovani, P. Allavena, A. Sica, and F. Balkwill, "Cancerrelated inflammation," Nature, vol. 454, no. 7203, pp. 436-444, 2008.

[47] S. P. Wasser and A. L. Weis, "Medicinal properties of substances occurring in higher Basidiomycetes mushrooms: current prespectives," International Journal of Medicinal Mushrooms, vol. 1, pp. 31-62, 1999.

[48] S. T. Chang and P. G. Miles, Mushrooms: Cultivation, Nutritional Value, Medicinal Eeffect and Environmental Impact, CRC Press, Boca Raton, Fla, USA, 1st edition, 2004.

[49] S. Bernardshaw, E. Johnson, and G. Hetland, "An extract of the mushroom Agaricus blazei murill administered orally protects against systemic Streptococcus pneumoniae infection in mice," Scandinavian Journal of Immunology, vol. 62, no. 4, pp. 393-398, 2005.

[50] J. L. Gonçalves, E. H. Roma, A. C. Gomes-Santos et al., "Proinflammatory effects of the mushroom Agaricus blazei and its consequences on atherosclerosis development," European Journal of Nutrition, vol. 51, no. 8, pp. 927-937, 2012.

[51] H.-H. Song, H.-S. Chae, S.-R. Oh, H.-K. Lee, and Y.-W. Chin, "Anti-inflammatory and anti-allergic effect of Agaricus blazei extract in bone marrow-derived mast cells," The American Journal of Chinese Medicine, vol. 40, no. 5, pp. 1073-1084, 2012.

[52] E. Johnson, D. T. Førland, L. Sætre, S. V. Bernardshaw, T. Lyberg, and G. Hetland, "Effect of an extract based on the medicinal mushroom agaricus blazei murill on release of cytokines, chemokines and leukocyte growth factors in human blood ex vivo and in vivo," Scandinavian Journal of Immunology, vol. 69, no. 3, pp. 242-250, 2009.

[53] D. T. Førland, E. Johnson, L. Sætre, T. Lyberg, I. Lygren, and G. Hetland, "Effect of an extract based on the medicinal mushroom Agaricus blazei Murill on expression of cytokines and calprotectin in patients with ulcerative colitis and Crohn's disease," Scandinavian Journal of Immunology, vol. 73, no. 1, pp. 66-75, 2011.

[54] L. K. Ellertsen and G. Hetland, "An extract of the medicinal mushroom Agaricus blazei Murill can protect against allergy," Clinical and Molecular Allergy, vol. 7, article 6, 2009.

[55] K. Wisitrassameewong, S. C. Karunarathna, N. Thongklang et al., "Agaricus subrufescens: a review," Saudi Journal of Biological Sciences, vol. 19, no. 2, pp. 131-146, 2012.

[56] S. Bernardshaw, G. Hetland, L. K. Ellertsen, A. M. A. Tryggestad, and E. Johnson, "An extract of the medicinal mushroom Agaricus blazei Murill differentially stimulates production of pro-inflammatory cytokines in human monocytes and human vein endothelial cells in vitro," Inflammation, vol. 29, no. 4-6, pp. 147-153, 2005.

[57] I. Lavi, L. Nimri, D. Levinson, I. Peri, Y. Hadar, and B. Schwartz, "Glucans from the edible mushroom Pleurotus pulmonarius inhibit colitis-associated colon carcinogenesis in mice," Journal of Gastroenterology, vol. 47, no. 5, pp. 504-518, 2012.
[58] I. Lavi, D. Levinson, I. Peri, L. Nimri, Y. Hadar, and B. Schwartz, "Orally administered glucans from the edible mushroom Pleurotus pulmonarius reduce acute inflammation in dextran sulfate sodium-induced experimental colitis," British Journal of Nutrition, vol. 103, no. 3, pp. 393-402, 2010.

[59] B. Schwartz, Y. Hadar, and D. Silva, "The use of edible mushroom water soluble polysaccharides in the treatment and prevention of chronic diseases: a mechanistic approach," in Antitumor Potential and other Emerging Medicinal Properties of Natural Compounds, pp. 263-283, Springer, Dordrecht, The Netherlands, 2013.

[60] F. R. Smirdele, L. M. Olsen, E. R. Carbonero et al., "Antiinflammatory and analgesic properties in a rodent model $(1 \rightarrow$ 3), ( $1 \rightarrow 6)$-linked-glucan isolated from Pleurotus pulmonarius," European Journal of Pharmacology, vol. 597, pp. 8-91, 2008.

[61] P. Bobek, V. Nosalova, and S. Cerna, "Effect of pleuran (betaglucan from Pleurotus ostreatus) in diet or drinking fluid on colitis in rats," Nahrung, vol. 45, pp. 360-363, 2001.

[62] A. Jedinak, S. Dudhgaonkar, Q.-L. Wu, J. Simon, and D. Sliva, "Anti-inflammatory activity of edible oyster mushroom is mediated through the inhibition of NF- $\kappa \mathrm{B}$ and AP-1 signaling," Nutrition Journal, vol. 10, no. 1, article 52, 2011.

[63] L. S. Queiroz, M. S. Nascimento, A. K. M. Cruz et al., "Glucans from the Caripia montagnei mushroom present anti-inflammatory activity," International Immunopharmacology, vol. 10, no. 1, pp. 34-42, 2010.

[64] A. C. Ruthes, E. R. Carbonero, M. M. Córdova et al., "Lactarius rufus $(1 \rightarrow 3),(1 \rightarrow 6)-\beta$-d-glucans: structure, antinociceptive and anti-inflammatory effects," Carbohydrate Polymers, vol. 94, no. 1, pp. 129-136, 2013.

[65] A. C. Ruthes, Y. D. Rattmann, S. M. Malquevicz-Paiva et al., "Agaricus bisporus fucogalactan: structural characterization and pharmacological approaches," Carbohydrate Polymers, vol. 92, no. 1, pp. 184-191, 2013.

[66] E. R. Carbonero, A. H. P. Gracher, D. L. Komura et al., "Lentinus edodes heterogalactan: antinociceptive and anti-inflammatory effects," Food Chemistry, vol. 111, no. 3, pp. 531-537, 2008.

[67] N. Fangkrathok, J. Junlatat, and B. Sripanidkulchai, "In vivo and in vitro anti-inflammatory activity of Lentinus polychrous extract," Journal of Ethnopharmacology, vol. 147, no. 3, pp. 631637, 2013.

[68] Y.-Y. Lu, Z.-H. Ao, Z.-M. Lu et al., "Analgesic and anti-inflammatory effects of the dry matter of culture broth of Termitomyces albuminosus and its extracts," Journal of Ethnopharmacology, vol. 120, no. 3, pp. 432-436, 2008.

[69] S.-H. Kim, Y.-S. Song, S.-K. Kim, B.-C. Kim, C.-J. Lim, and E.-H. Park, "Anti-inflammatory and related pharmacological activities of the $\mathrm{n}-\mathrm{BuOH}$ subfraction of mushroom Phellinus linteus," Journal of Ethnopharmacology, vol. 93, no. 1, pp. 141146, 2004.

[70] B.-C. Kim, J.-W. Choi, H.-Y. Hong et al., "Heme oxygenase-1 mediates the anti-inflammatory effect of mushroom Phellinus linteus in LPS-stimulated RAW264.7 macrophages," Journal of Ethnopharmacology, vol. 106, no. 3, pp. 364-371, 2006.

[71] H. Li, X. Lu, S. Zhang, M. Lu, and H. Liu, "Anti-inflammatory activity of polysaccharide from Pholiota nameko," Biochemistry, vol. 73, no. 6, pp. 669-675, 2008.

[72] D.-M. Wu, W.-Q. Duan, Y. Liu, and Y. Cen, "Anti-inflammatory effect of the polysaccharides of Golden needle mushroom in burned rats," International Journal of Biological Macromolecules, vol. 46, no. 1, pp. 100-103, 2010. 
[73] R. O. Diniz, L. K. Garla, J. M. Schneedorf, and J. C. T. Carvalho, "Study of anti-inflammatory activity of Tibetan mushroom, a symbiotic culture of bacteria and fungi encapsulated into a polysaccharide matrix," Pharmacological Research, vol. 47, no. 1, pp. 49-52, 2003.

[74] I. Tsvetkova, H. Naydenski, A. Petrova et al., "Antibacterial activity of some Bulgarian higher Basidiomycetes mushrooms," International Journal of Medicinal Mushrooms, vol. 8, no. 1, pp. 63-66, 2006.

[75] H. Fujimoto, Y. Nakayama, and M. Yamazaki, "Identification of immunosuppressive components of a mushroom, Lactarius flavidulus," Chemical \& Pharmaceutical Bulletin, vol. 41, no. 4, pp. 654-658, 1993.

[76] J. Han, Y. Chen, L. Bao et al., "Anti-inflammatory and cytotoxic cyathane diterpenoids from the medicinal fungus Cyathus africanus," Fitoterapia, vol. 84, no. 1, pp. 22-31, 2013.

[77] Z. Xu, S. Yan, K. Bi et al., "Isolation and identification of a new anti-inflammatory cyathane diterpenoid from the medicinal fungus Cyathus hookeriBerk," Fitoterapia, vol. 86, no. 1, pp. 159$162,2013$.

[78] S. Dudhgaonkar, A. Thyagarajan, and D. Sliva, "Suppression of the inflammatory response by triterpenes isolated from the mushroom Ganoderma lucidum," International Immunopharmacology, vol. 9, no. 11, pp. 1272-1280, 2009.

[79] K. Iwatsuki, T. Akihisa, H. Tokuda et al., "Lucidenic acids P and $\mathrm{Q}$, methyl lucidenate $\mathrm{P}$, and other triterpenoids from the fungus Ganoderma lucidum and their inhibitory effects on EpsteinBarr virus activation," Journal of Natural Products, vol. 66, no. 12, pp. 1582-1585, 2003.

[80] T. Akihisa, M. Tagata, M. Ukiya, H. Tokuda, T. Suzuki, and Y. Kimura, "Oxygenated lanostane-type triterpenoids from the fungus Ganoderma lucidum," Journal of Natural Products, vol. 68, no. 4, pp. 559-563, 2005.

[81] T. Akihisa, Y. Nakamura, M. Tagata et al., "Anti-inflammatory and anti-tumor-promoting effects of triterpene acids and sterols from the fungus Ganoderma lucidum," Chemistry and Biodiversity, vol. 4, no. 2, pp. 224-231, 2007.

[82] Q. Van, B. N. Nayak, M. Reimer, P. J. H. Jones, R. G. Fulcher, and C. B. Rempel, "Anti-inflammatory effect of Inonotus obliquus, Polygala senega L., and Viburnum trilobum in a cell screening assay," Journal of Ethnopharmacology, vol. 125, no. 3, pp. 487493, 2009.

[83] Y.-M. Park, J.-H. Won, Y.-H. Kim, J.-W. Choi, H.-J. Park, and K.-T. Lee, "In vivo and in vitro anti-inflammatory and antinociceptive effects of the methanol extract of Inonotus obliquus," Journal of Ethnopharmacology, vol. 101, no. 1-3, pp. 120-128, 2005.

[84] L. Ma, H. Chen, P. Dong, and X. Lu, "Anti-inflammatory and anticancer activities of extracts and compounds from the mushroom Inonotus obliquus," Food Chemistry, vol. 139, no. 1-4, pp. 503-508, 2013.

[85] J. Wang, Y.-M. Liu, W. Cao, K.-W. Yao, Z.-Q. Liu, and J.-Y. Guo, "Anti-inflammation and antioxidant effect of cordymin, a peptide purified from the medicinal mushroom Cordyceps sinensis, in middle cerebral artery occlusion-induced focal cerebral ischemia in rats," Metabolic Brain Disease, vol. 27, no. 2, pp. 159-165, 2012.

[86] G.-M. Qian, G.-F. Pan, and J.-Y. Guo, "Anti-inflammatory and antinociceptive effects of cordymin, a peptide purified from the medicinal mushroom Cordyceps sinensis," Natural Product Research, vol. 26, no. 24, pp. 2358-2362, 2012.
[87] J. H. Wong, T. B. Ng, H. Wang et al., "Cordymin, an antifungal peptide from the medicinal fungus Cordyceps militaris," Phytomedicine, vol. 18, no. 5, pp. 387-392, 2011.

[88] Y. Zhang, G. L. Mills, and M. G. Nair, "Cyclooxygenase inhibitory and antioxidant compounds from the fruiting body of an edible mushroom, Agrocybe aegerita," Phytomedicine, vol. 10, no. 5, pp. 386-390, 2003.

[89] B. Dugler, A. Gonuz, and F. Gucin, "Antimicrobial activity of the macrofungus Cantharellus cibarius," Pakistan Journal of Biological Sciences, vol. 7, pp. 1535-1539, 2004.

[90] A. M. Witkowska, M. E. Zujko, and I. Mirończuk-Chodakowska, "Comparative study of wild edible mushrooms as sources of antioxidants," International Journal of Medicinal Mushrooms, vol. 13, no. 4, pp. 335-341, 2011.

[91] C. Moro, I. Palacios, M. Lozano et al., "Anti-inflammatory activity of methanolic extracts from edible mushrooms in LPS activated RAW 264.7 macrophages," Food Chemistry, vol. 130, no. 2, pp. 350-355, 2012.

[92] D. N. Quang, L. Harinantenaina, T. Nishizawa et al., "Inhibitory activity of nitric oxide production in RAW 264.7 cells of daldinals A-C from the fungus Daldinia childiae and other metabolites isolated from inedible mushrooms," Journal of Natural Medicines, vol. 60, no. 4, pp. 303-307, 2006.

[93] M. Nukata, T. Hashimoto, I. Yamamoto, N. Iwasaki, M. Tanaka, and Y. Asakawa, "Neogrifolin derivatives possessing anti-oxidative activity from the mushroom Albatrellus ovinus," Phytochemistry, vol. 59, no. 7, pp. 731-737, 2002.

[94] D. N. Quang, T. Hashimoto, Y. Arakawa et al., "Grifolin derivatives from Albatrellus caeruleoporus, new inhibitors of nitric oxide production in RAW 264.7 cells," Bioorganic and Medicinal Chemistry, vol. 14, no. 1, pp. 164-168, 2006.

[95] M. Ye, J. K. Liu, Z. X. Lu et al., "Grifolin, a potential antitumor natural product from the mushroom Albatrellus confluens, inhibits tumor cell growth by inducing apoptosis in vitro," FEBS Letters, vol. 579, no. 16, pp. 3437-3443, 2005.

[96] R. Stanikunaite, S. I. Khan, J. M. Trappe, and S. A. Ross, "Cyclooxygenase- 2 inhibitory and antioxidant compounds from the truffle Elaphomyces granulatus," Phytotherapy Research, vol. 23, no. 4, pp. 575-578, 2009.

[97] C. Han and B. Cui, "Pharmacological and pharmacokinetic studies with agaricoglycerides, extracted from Grifola frondosa, in animal models of pain and inflammation," Inflammation, vol. 35, no. 4, pp. 1269-1275, 2012.

[98] P. H. K. Ngai, Z. Zhao, and T. B. Ng, "Agrocybin, an antifungal peptide from the edible mushroom Agrocybe cylindracea," Peptides, vol. 26, no. 2, pp. 191-196, 2005.

[99] D. Michelot and L. M. Melendez-Howell, "Amanita muscaria: chemistry, biology, toxicology, and ethnomycology," Mycological Research, vol. 107, no. 2, pp. 131-146, 2003.

[100] S.-Y. Won and E.-H. Park, "Anti-inflammatory and related pharmacological activities of cultured mycelia and fruiting bodies of Cordyceps militaris," Journal of Ethnopharmacology, vol. 96, no. 3, pp. 555-561, 2005.

[101] K.-M. Kim, Y.-G. Kwon, H.-T. Chung et al., "Methanol extract of Cordyceps pruinosa inhibits in vitro and in vivo inflammatory mediators by suppressing NF- $\kappa \mathrm{B}$ activation," Toxicology and Applied Pharmacology, vol. 190, no. 1, pp. 1-8, 2003.

[102] J.-J. Cheng, C.-Y. Lin, H.-S. Lur, H.-P. Chen, and M.-K. Lu, "Properties and biological functions of polysaccharides and ethanolic extracts isolated from medicinal fungus, Fomitopsis pinicola," Process Biochemistry, vol. 43, no. 8, pp. 829-834, 2008. 
[103] Y. Zhang, G. L. Mills, and M. G. Nair, "Cyclooxygenase inhibitory and antioxidant compounds from the mycelia of the edible mushroom Grifola frondosa," Journal of Agricultural and Food Chemistry, vol. 50, no. 26, pp. 7581-7585, 2002.

[104] C. M. P. Guerra Dore, T. C. G. Azevedo, M. C. R. de Souza et al., "Antiinflammatory, antioxidant and cytotoxic actions of $\beta$ glucan-rich extract from Geastrum saccatum mushroom," International Immunopharmacology, vol. 7, no. 9, pp. 1160-1169, 2007.

[105] T. Debnath, M. A. Hasnat, M. Pervin et al., "Chaga mushroom (Inonotus obliquus) grown on germinated brown rice suppresses inflammation associated with colitis in mice," Food Science and Biotechnology, vol. 21, no. 5, pp. 1235-1241, 2012.

[106] Y. Ukawa, H. Ito, and M. Hisamatsu, "Antitumor effects of $(1 \rightarrow$ $3)-\beta$-D-glucan and $(1 \rightarrow 6)-\beta$-D-glucan purified from newly cultivated mushroom, Hatakeshimeji (Lyophyllum decastes Sing)," Journal of Bioscience and Bioengineering, vol. 90, no. 1, pp. 98-104, 2000.

[107] B.-C. Kim, W.-K. Jeon, H.-Y. Hong et al., "The anti-inflammatory activity of Phellinus linteus (Berk. \& M.A. Curt.) is mediated through the $\mathrm{PKC} \delta / \mathrm{Nrf} 2 / \mathrm{ARE}$ signaling to up-regulation of heme oxygenase-1," Journal of Ethnopharmacology, vol. 113, no. 2, pp. 240-247, 2007.

[108] M.-K. Lu, J.-J. Cheng, C.-Y. Lin, and C.-C. Chang, "Purification, structural elucidation, and anti-inflammatory effect of a watersoluble 1,6-branched 1,3- $\alpha$-d-galactan from cultured mycelia of Poria cocos," Food Chemistry, vol. 118, no. 2, pp. 349-356, 2010. 


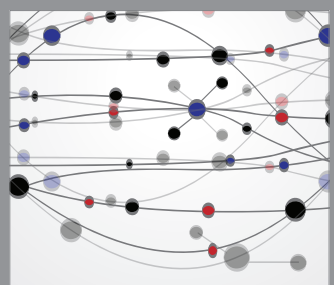

The Scientific World Journal
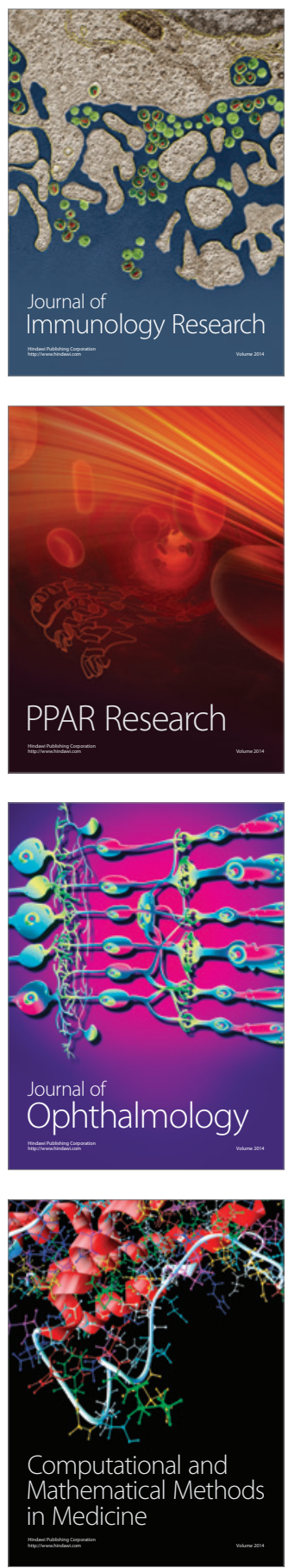

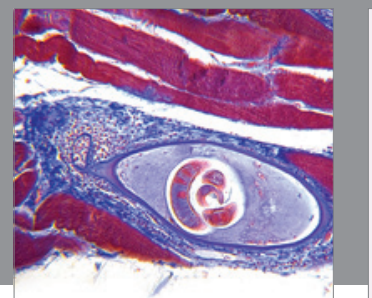

Gastroenterology

Research and Practice
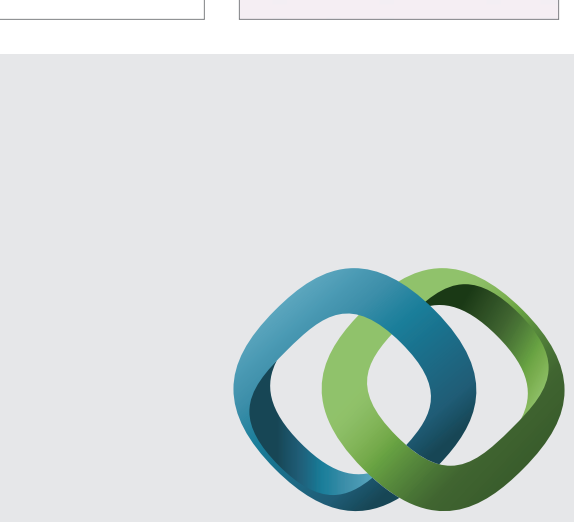

\section{Hindawi}

Submit your manuscripts at

http://www.hindawi.com
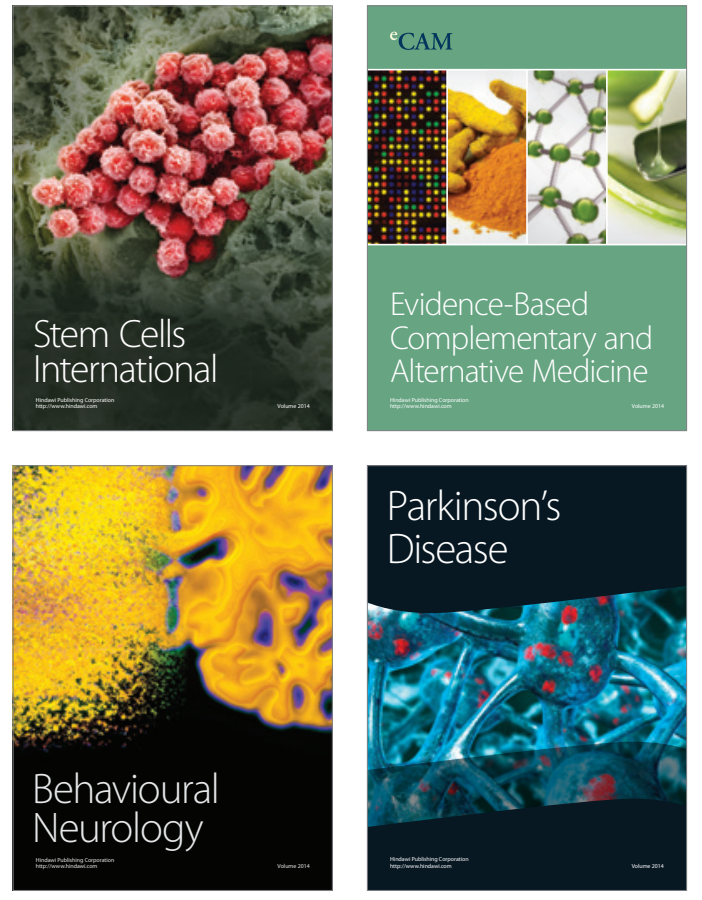
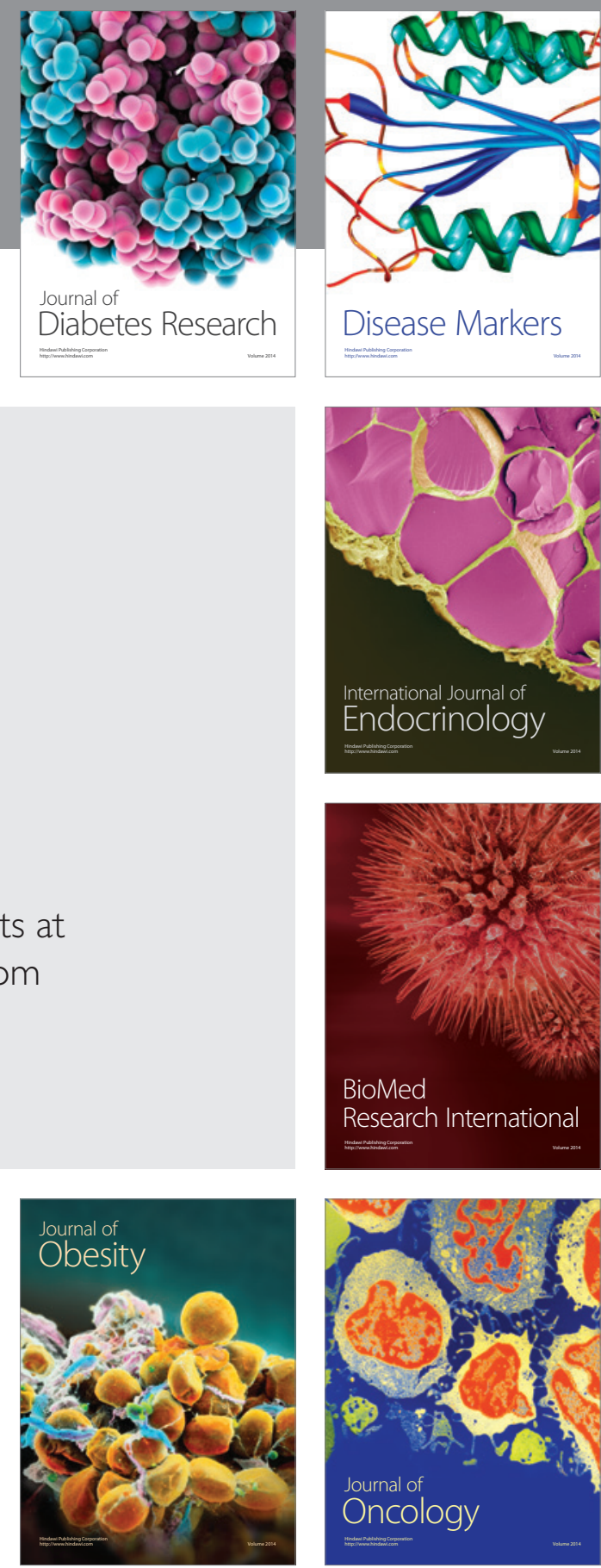

Disease Markers
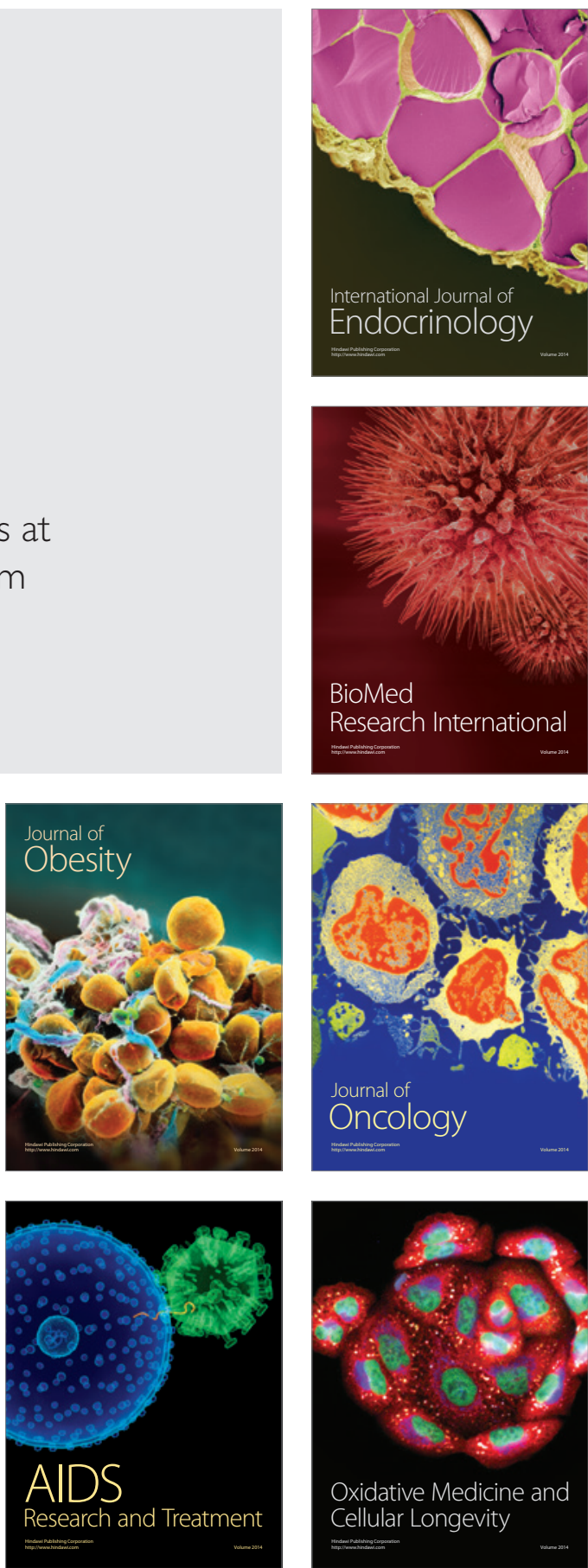